\title{
Towards Employee Wellness: Rethinking Bullying Paradoxes and Masks
}

\author{
Margaret H. Vickers
}

Published online: 21 November 2006

(C) Springer Science + Business Media, Inc. 2006

\begin{abstract}
Wellness in organizations" should focus on the well being of individual workers. At a time when the wellness of individuals is increasingly being threatened in our workplaces, I argue that one way wellness can be sought is through careful examination of routine organizational practices. To make this point, I look to the problem of bullying in organizations and, in particular, traditional organizational responses to bullying. The paradoxes of protective legislation and protective workplace policies are explored, before numerous organizational masks that serve to bolster these paradoxes are discussed: the mask of stereotypes; the mask of Alternative Dispute Resolution (ADR); the mask of counseling; and the mask of training. The way towards wellness in organizations lies with the recognition of unintended distortions and limitations on existing legislation, policy and process, and the critical assessment of traditional remedies.
\end{abstract}

Key words bullying $\cdot$ employee wellness $\cdot$ Alternative Dispute Resolution $($ ADR $) \cdot$ mediation

\section{“Organizational Wellness" or "Wellness in Organizations?"}

There can be no health or wellness in organizations without careful attention to the well being of individual employees. Perhaps, rather than thinking about "organizational wellness," a more useful mantra might be "wellness in organizations." My concern with wellness in organizations is with the welfare of individuals in the organizational context; it is about their wellness, well being and contentment as individuals go about their working day. It is

M. H. Vickers $(\bowtie)$

School of Management, University of Western Sydney,

c/- 235 Mowbray Road, CHATSWOOD,

Sydney, NSW 2067, Australia

e-mail: m.vickers@uws.edu.au 
also about good health, relative to that person's "normal" level of health. Just as a "healthy" person can become very sick, stressed and depressed in a toxic work environment, a chronically ill or disabled person can, within the bounds of their existing limitations, become productive and contented, with their general level of "health" improving and stabilizing in a supportive, compassionate working environment.

There has, simply, been too little consideration of the wellness and health of individuals in the organizational context, and certainly not in a way that reflects real concern for the individual and their circumstances. I note that some have promoted organizational wellness via the application of behavioural science principles to the workplace setting, producing benefits for the organization (Adkins, 1999, p. 129; my emphasis). Others have conceptualized health in organizations in the same manner as the medical model, with health and well being determined by an absence of disease - not for the individual, but for the organization as an entity. Organizational wellness has also been characterized as a state of optimal functioning for the organization (Tetrick, 2002).

However, in my view, wellness in organizations is intimately tied to the well being of that organization's individual members. Without sufficient address of the needs of individuals and consideration being aligned with the myriad of issues that might arise for them, the well being of the organization as a whole will undoubtedly suffer. Individuals in trouble are not receiving adequate support or consideration.

In recent times we have seen a burgeoning list of reasons why organizations should be concerned about the health and well being of individual workers. Many have written about the problems individuals face as they wrestle with engagement with the organization in a meaningful and productive way. We have learned of toxic workplaces and toxic emotions at work (Frost, 2003); emotionally anorexic workplaces (Fineman, 1993); the personal cost for those exposed to redundancies and downsizing (Stein, 1998, 2001; Vickers, 2002); bullying and violence at work (Barron, 2002; Mann, 1996; Quine, 1999; Randall, 1997; Rees, 1995; Vickers, 2001b); alienating workplaces (Blauner, 1964; Braverman, 1994; Fromm, 1963/1994; La Bier, 1986); abusive workplaces (Perrone \& Vickers, 2004; Powell, 1998); the traumatized worker (Vickers, 2004); the work-home conflict, especially as it pertains to caregiving responsibilities for full time workers (Vickers, Parris \& Bailey, 2004); and that those with chronic illness and disability (whether caused at work or not) are simply not gaining sufficient support in their efforts to remain gainfully employed (Thomson \& Dunstan, 2002; Vickers, 1998, 1999, 2001a). At a time when claims are being made that work is becoming more central to our lives and identities (Trinca \& Fox, 2004), the health (physical, mental, emotional, spiritual and psychological) of the individual at work should be of primary concern.

In contrast, the wellness of the organization continues to take precedence. If concerns arise as a result of workplace accidents and injuries, violence and bullying, depression and stress, inappropriate surveillance, discrimination, casualization of workers, downsizing and redundancies, organizational change, toxic workplaces, or unrelenting, uncritical (and uninformed) managerialism, I contend that any organizational response to individuals in trouble takes place only when the organization has to, and in a means that is in the interests of the organization, not the individual. This may be to: earn more for shareholders; respond to unfavourable media scrutiny; protect from litigation; to "corral" staff and union complaints in the internal arena; or to present a warm and caring public relations image. None 
of these motives mesh with the wellness of individual workers. Indeed, we have known that the objectives of management and labour have long been at odds. In order to promote workplaces where individual well being is valued, the focus must shift from the organization, to the needs of the individual employee.

One way that wellness in organizations for individuals can be encouraged is by turning our attention to the routine practices, policies and procedures that individuals are exposed to. Many of these have the unintended outcomes that may undermine individual wellness. I attempt to illustrate this by examining the problem of bullying in Australian organizations; in particular, the typical organizational responses to complaints of bullying, and the paradoxical and masking effects that these routine responses may have. It is hoped that this analysis of Australian process will have lessons for other nations similarly placed. I claim that many unintended, paradoxical outcomes can produce further harm to individual workers so that, instead of assisting those targeted by bullies, the organizational responses serve, instead, to protect the organization, protect the bully, protect the status quo, conceal the real intention of bullies and generally make life for a target of bullying more difficult. The continued legitimization of such practices continues to undermine the well being of those affected.

\section{Bullying: Why Traditional Responses do not Promote Wellness}

Bullying involves the persistent embarrassment and humiliation of a person, and includes the deliberate, hurtful, repeated actions intended to cause harm. Bullying includes hostile physical and nonphysical behaviour designed to negatively impact the target's sense of self as a competent person. It includes persistent, offensive, abusive, intimidating, malicious or insulting behaviour, abuse of power and unfair penal sanctions, making the target feel upset, threatened, humiliated or vulnerable. This, in turn, can undermine confidence, and cause stress (Lee, 2002, p. 205). The emerging literature confirms that workplace bullying inflicts harmful, even devastating, effects on its targets and can sabotage morale, and undercut productivity and loyalty (Hutchinson, Vickers, Jackson, \& Wilkes, 2005, 2006a; Yamada, 2000, p. 476).

There is now extensive evidence that bullying has a severe impact on individuals, as does mobbing $^{1}$ (Hutchinson et al., 2005, 2006a, b; Mayhew et al., 2004). For example, Leymann and Gustaffsson (1996; cited in Mayhew et al., 2004) found that the Post Traumatic Stress Disorder (PSTD) reactions of train drivers smashing into suicidees was milder and less extensive than the trauma experienced by targets of long term mobbing (Leymann \& Gustaffsson, 1996; Mayhew et al., 2004). Witnesses to bullying can also be negatively affected, with up to $20 \%$ of witnesses deciding to leave the organization as a result of their experience (Mayhew et al., 2004).

Bullying has been characterized by some as emotional abuse, including hostile verbal and nonverbal, nonphysical behaviours (Yamada, 2000, p. 478). Bullying includes harassment (both sexual and racial), aggression and violent behaviour (House of

\footnotetext{
${ }^{1}$ For those unfamiliar, the term "mobbing" refers to bullying incidents with multiple perpetrators (Mayhew et al., 2004; Zapf, 1999).
} 
Representatives Standing Committee on Employment Education and Training, 1995, p. 21), with the key concern being the intention to harm; whether the attack was successful or not does not matter (Felson, 2000, p. 10). Bullies often use many types of insults as part of a deliberate and concerted strategy: exclusion, stereotyping, obliteration of significant identity details (for example, spelling a name incorrectly), rudeness, broken promises, ignoring and keeping the target waiting, as well as ingratitude (Gabriel, 1998). In sum, workplace bullying is the intentional infliction of a hostile work environment upon an employee by a coworker, typically through a combination of verbal and nonverbal behaviours (Yamada, 2000, p. 479). Bullying is frequently an abuse of power (McMahon, 2000, p. 384; cited in Simpson \& Cohen, 2004).

Bullying, especially predatory bullying, impacts the well being of those targeted, by providing a hostile, harmful and toxic work environment that encourages stress, depression, sleeplessness and anxiety. Unfortunately, bullying is often trivialized and minimalized in organizations as being something less destructive than it really is. The euphemistic label of 'bully' contributes to this, with inappropriate visions of harmless schoolboy pranks allowing the bully to effectively hide behind the organization and its processes. Sadly, the organization's response to bullying often serves to exacerbate the target's experience of being bullied, especially if their reported experiences are minimalized, dismissed, ignored, disbelieved, or allowed to continue without action. Even when organizations do take action, we will see that unintended outcomes may actually worsen the experience for individuals affected.

\section{Paradoxical Responses to Bullying}

A paradox is a seemingly absurd or self-contradictory statement that is or may be true. It can also be a self-contradictory proposition or something exhibiting apparently contradictory characteristics, and can also encompass an opinion that conflicts with common beliefs (Wilkes, 1979, p. 1063). I claim that many of the traditional responses to bullying are paradoxical in nature, with the potential to exhibit contradictory, even absurd, characteristics. They do not promote wellness for targets of bullying. The following sections are based on Australian examples, however, the points raised remain relevant in many Western nations.

\section{The Paradox of Protective Legislation}

Despite the existence of legislation intended to protect targets of bullying, much legislation, especially in Australia, does not explicitly cover much of what constitutes bullying behaviour. The Australian legal system tends not to recognize many bullying behaviours as being criminal. ${ }^{2}$ The bullying behaviour frequently falls outside the purview of current

\footnotetext{
${ }^{2}$ Workplace violence is a form of bullying that could be classed as a criminal offence-if it occurred outside the work setting. For example, assaults, threats, damage to property, verbal obscenities, or sexual harassment (Barron, 2002: 152) would constitute criminal actions. However, when corralled within the institutional arena, events like these may be trivialized. An assault becomes an "argument" or a "slap"; threats to personal safety and belongings become a "dispute" or "conflict." Regardless of where it takes place, it remains the responsibility of the complainant to prove the allegation.
} 
discrimination or occupational health and safety statutes. In Australia, these would include legislation such as the NSW Anti-Discrimination Act 1977 (NSW Government Information Service, 1977), the Federal Disability Discrimination Act 1992 (Commonwealth of Australia, 1996), the Sex Discrimination Act 1984 (Commonwealth of Australia, 1996), and the Occupational Health and Safety Act (Brooks, 1993).

Psychological aggression also injures workers. However, these are less likely to have recognized criminal elements and are difficult to prove under current legislation. Certainly in Australia, OHS legislation has yet to have had any successful prosecutions for stress related injury (even though we are assured that it is only a matter of time) (Dent, 2002). Many of the most damaging outcomes associated with bullying lie with repeated and supposedly "trivial" incidents. Taken in isolation, these may not be provable or of sufficient magnitude to damage one's health. For example, reported or witnessed incidents of rudeness, ingratitude, broken promises and exclusion may be difficult for others to perceive as "serious" and of concern. However, over time, they may well constitute serious, threatening and intimidating patterns of behaviour that are provocative, distressing and frightening.

Another paradoxical situation associated with legislative initiatives is that it is very difficult for the target to prove bullying behaviour. For example, when one considers the Occupational Health and Safety Act (Brooks, 1993), while breaches of this act are considered to be a crime that may result in gaol time and criminal records for offenders, the responsibility lays with the complainant to prove guilt 'beyond a reasonable doubt' (Dent, 2002). Bullying often takes place behind closed doors. Harrassment, abusive language, snide remarks, victimization, and lies are often perpetrated out of earshot of others. Incidents may be ignored in a culture where bullying has become normalized, or where prospective witnesses may be fearful of being targeted by the bully themselves. In the absence of witnesses or other physical evidence, it is difficult for the target to demonstrate the wrong that has been committed.

On the other hand, defending a complaint brought against a bully is much easier. Because bullying is often done without witnesses, or where witnesses are reluctant to come forward, it becomes the word of one against another. This is especially problematic in an institutional context where the bully may have more power and influence than the target. It is also easy for a bully in a powerful position to enlist (willingly or unwillingly) the cooperation of others to support them. Bullies are often surrounded by 'passive bullies, followers or henchmen,' individuals who may not necessarily initiate the aggressive behaviour, but participate, providing support to the bully (Olweus, 1994, p. 180). Passive bullies can be equally troubling to the victim (Ballard, Argus, \& Remley, 1999) as is 'mobbing,' where others are gathered willingly or unwillingly to participate in continuous malevolent actions (Yamada, 2000; Zapf, 1999).

Injured workers litigate for three main reasons: (1) for compensation or monetary gain; (2) for vindication, that is, to get the defendant to acknowledge the wrongdoing; and, (3) to achieve workplace reform (Thomson \& Dunstan, 2002). However, litigation is unlikely to achieve any of these goals. Getting the bully to acknowledge the wrongdoing and achieve workplace reform is a rare outcome indeed. Even if bullying can be proven in a legal setting, in Australia, the costs for a target to prepare and try a case are likely to be far higher than any likely award of damages made by a court. 
For example, if bullying were proven under the Federal Sex Discrimination Act 1984 or Disability Discrimination Act 1992, then determinations in favour of a complainant may include the payment of damages. However, it remains the responsibility of the complainant to demonstrate the damage to themselves and their career in monetary terms. It is difficult to estimate a damages amount on incidents, such as being lied to, excluded or belittled, especially if one cannot demonstrate directly the impact on one's career or earning capacity. Federal cases of this nature are handled in Australia by the Human Rights and Equal Opportunity Commission (Commonwealth of Australia, 1996 Disability Discrimination Act 1992: 36 ff; Section 67; Commonwealth of Australia, 1996 Sex Discrimination Act 1984: $37 \mathrm{ff}$; Section 48). Given the escalating number of complaints submitted, it can be months or years before cases come forward, further adding to the stress for the target.

At the state level, the NSW Anti Discrimination Act 1977 relies on a Tribunal holding an inquiry into a complaint of discrimination. If the complaint is substantiated the respondent may be ordered to pay the complainant damages not exceeding $\$ 40,000$ as compensation for the loss or damage suffered by reason of the respondent's conduct (NSW Government Information Service New South Wales Anti Discrimination Act 1977 p. 125; Section 113.1 (b) (ii)). However, awards of this magnitude are almost unheard of, with a more likely outcome being less than $\$ 10,000$ and, often, much less. In this setting, costs are paid by each party (win or lose) and it is, once again, up to the complainant to demonstrate in monetary terms the loss or damage suffered as a result of the actions of the bully. It is entirely possible that complaints be substantiated with the unhappy outcome for the target being: (a) that costs far exceed the compensation awarded (this is highly likely with complaints involving repeated incidents or complex cases involving numerous witnesses); or, (b) that a monetary compensation for loss or damage may be difficult to demonstrate, thus reducing the award. In Australia, the cost of solicitor might be \$200-400 per hour. The cost of engaging a barrister for court appearances and preparation rises to $\$ 3,000-5,000$ per day. Thus, it is unlikely that complainants would benefit financially or otherwise from the process of litigating a bullying complaint.

Further, when one considers the so-called protective intent of such litigation, the evidence suggests that the stress effects of litigation are devastating, long-lasting and, potentially, very damaging. Litigation is recognized as a significant stressor for an injured or bullied worker (Thomson \& Dunstan, 2002). If the complainant loses their job during the litigation or as a result of it, this provides a further stressor for the complainant. Stress induced by litigation heightens psychological symptoms experienced, such as psychological distress and depression (Thomson \& Dunstan, 2002), and for some litigants, psychological symptoms do not dissipate after settlement, particularly for those who are no longer gainfully employed. The more stressful the compensation process, the greater the disability, pain and psychological distress (Thomson \& Dunstan, 2002).

\section{The Paradox of Protective Workplace Policies}

Workplace policies to protect against bullying are increasingly being developed by employers. I include an example taken from one Australian university website. There are many such policies freely available on the internet and I emphasize that the comments made 
here about such policies are of a general kind, and not directed specifically at this institution:

The University of Western Sydney (UWS) is committed to providing an environment which recognizes and respects the diversity of staff and students within the UWS community. UWS is committed to providing a work and study environment free from harassment, vilification and bullying and supports the right of all staff and students to work and study in a safe and healthy environment free from such behaviour.

The University recognizes that harassment, vilification and bullying demeans and infringes the rights of individuals and groups, damaging the work and study environment. Harassment, vilification and bullying will not be tolerated at UWS.

The University will ensure that complainants to harassment, vilification and bullying will not be victimized for making a complaint.

Bullying behaviour can refer to the actions or behaviours of a person to another that intimidates, degrades or humiliates the person. It may include verbal abuse, behaviour intended to punish such as isolation, exclusion from workplace activities and 'ganging up'. Repeated 'put-downs', aggression, threats and poorly managed conflicts of opinion may also be part of bullying behaviour. It can occur between people such as: supervisors and staff, co-workers, classmates and by any gender (University of Western Sydney, 2003).

Many workplaces have or are implementing policies like this one. They are ostensibly designed to protect targets, to encourage reporting and to reinforce the public perception that bullying and harassment will not be tolerated at the institution concerned.

However, there may be another possible explanation. Their utility may also lay with encouraging complainants to report the problem within the institutional context (as opposed to following a litigious path). This serves to confine the complaint within the boundaries of the organization. The paradox is clear: policies professing to protect targets may actually be in place to protect the institution from the gaze of external parties, such as lawyers, insurance and human rights agencies, police and the media. ${ }^{3}$

As noted above, injured or bullied employees can bring complaints under legislation such as the Occupational Health and Safety Act in Australia. This legislation demands that employers have a duty of care to deliver safe systems and safe places of work (Dent, 2002). Further, employees of the organization (including bullies) have a duty to take reasonable care for the health and safety of persons who are at their place of work. All employees are required, under the act, to co-operate with their employer regarding managing the organization's obligations under the Act (Dent, 2002). However, Dent (2002) confirms that one defense used by employers against charges brought under this Act is managers being able to demonstrate that they have used all due diligence to prevent the contravention by the corporation. Indeed, Dent's recommendations to protect employers against potential

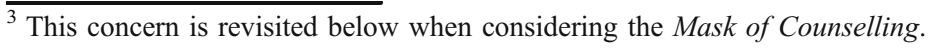


changes include (among others) the development of OHS policies, the training of staff in their legal obligations, ${ }^{4}$ and the discipline and termination of offenders.

Finally, vivifying the paradox further is that policies like these-even when they do operate to protect the target - are entirely dependent on the target's actions to be enacted. The target must take their time and energy, risk alienation and ostracism, career disruption (or unemployment), increased stress and an associated increased risk of substance abuse, relationship and family detriments, and negative health outcomes, such as the exacerbation of current chronic health conditions or the commencement of others, to follow through such a complaint.

\section{Masks and Bullying}

Masks are used to cover up, to hide or to conceal. Masks are also used to make indistinct or imperceptible, to cover something for protection, or to modify its shape (Penguin English Dictionary, 1992 p. 567). When considering organizations and their responses to bullying, it is important that attention be paid to the notion that masks are not just a cover for disguise or protection. Masks may also represent a grotesque, false face as worn in rituals (Penguin English Dictionary, 1992 p. 567). I now consider four ways that masks operate in institutions to bolster the paradox and highlight the absurdity of some traditional responses to bullying.

Masks can operate to trivialize serious process deficiencies, normalize unacceptable behaviour, and distort, sometimes grotesquely, the inappropriate legitimization and concealment of propositions espoused to help, support and ameliorate. Bullying can manifest in prolonged psychological and emotional harm, verbal abuse, as well as undermining and humiliation of the target. It may also ultimately result in violence. I argue that masks operating hand in glove with bullying may magnify the problem.

\section{The Mask of Stereotyping}

Stereotyping acts to distort or conceal the truth about the people involved in complaints of bullying - in this case, the target and the bully. Stereotyping can provide a grotesque caricature of both bullies and targets, serving ultimately to support the bully and undermine the target. For instance, many assume incorrectly that targets are people who 'put up with' bullying; that they are somehow to blame. Targets are frequently credited with being poor communicators and insufficiently assertive. They are also, often, wrongly accused of lacking a sense of humour, being overly sensitive, or inclined to being paranoid.

However, unlike the stereotypes, people targeted by bullies have been found to be, frequently, more attractive, confident, successful, qualified or popular than are the perpetrators (Gaymer, 1999; Mayhew \& Chappell, 2001; Wallis Consulting, 2001). Indeed, targets may be selected precisely because they are incorruptible, have high standards, and are prepared to speak out. Targets often gain recognition for their achievements, providing a further source of irritation to the bully. Contrary to popular belief, targets are highly

$\overline{4}$ I will also return to this below when considering The Mask of Training. 
unlikely to be downtrodden, unassertive people who 'just can't stand up for themselves.' Instead, they are more likely to be excellent performers, good at their job, popular with others, prepared to stand up for others, and blow the whistle on incompetence, malpractice, fraud, or illegality. Targets may be vulnerable, though, through recent bereavement, illness, being younger or older than most, or being known to be the main breadwinner.

Stereotypes attaching to bullies are equally flawed. Bullies are often perceived and depicted as being loud, aggressive, strong and assertive - in control. In reality, they are more likely to be jealous, weak, and lacking in confidence. They may also not necessarily be loud or inclined to be overbearing. Bullies often operate quietly, in the background. We know that managers of other staff are most likely to be perpetrators of bullying in organizations. Bullies have usually bullied before and bullies often target more than one person (Barron, 2002, p. 160). Bullying that is predatory is particularly likely to be malicious, irrational and unfair (Barron, 2002, p. 153) and bullying escalates over time. Importantly, bullying is always situated within the organization (Barron, 2002, p. 154; my emphasis).

\section{The Mask of Alternative Dispute Resolution (ADR)}

Alternative Dispute Resolution (ADR) strategies, particularly mediation, are gaining increasing popularity in solving many organizational disputes. They can offer a convenient, inexpensive, less time consuming means of resolving disputes and settling conflicts. However, we should be reminded that bullying, especially predatory or sociopathic bullying, is not a dispute or a conflict. In this case, ADRs may operate to mask the reality of what is going on, creating a parody of these supposedly impartial, neutral and ameliorating processes.

For example, if the target agrees to a mediation process, they implicitly accept some responsibility for what has happened and must, by definition, come to the table being prepared to share in a response to the "problem." Requesting the target's presence at mediation for a discussion with the perpetrator also demonstrates the (conscious or unconscious) belief that the victim is somehow responsible for the abuser's actions. The general implication is that both parties must change (A. R. Imbrogno \& S. Imbrogno, 2000, p. 398). It also confirms the flawed view that bullying is not a crime, but belongs within the jurisdiction of the organization - a management or human resources issue - and not a callous infringement of the rights of one individual (or individuals) by another (or others). Finally, mediation outcomes are non-enforceable. If the bully chooses to recommence the bullying behaviour, the whole complaint process will need to be recommenced by the target who, if not already, is now likely to be labeled as a "trouble-maker."

ADRs, like other social process, are imbued with varying degrees of social stereotypes and ideological baggage. I have already mentioned the mask of stereotyping above, but other social masks also operate to disadvantage targets and support bullies. For example, given the acknowledged patriarchy that continues in many communities and organizations, one can reasonably assume that the use of ADRs will, similarly, be tainted by patriarchal values and assumptions, especially if the process is determined by men and involves women. Women are oppressed, actively restrained, subordinated, moulded, and used and abused by men (A. R. Imbrogno \& S. Imbrogno, 2000, p. 394). The potential for internal 
dispute resolution strategies as another means of restraint and oppression must be considered. It is also important to note that ADRs are not designed for application in situations where there is a power imbalance. Indeed, it has been noted that effective mediation is impossible when the parties have unequal power (A. R. Imbrogno \& S. Imbrogno, 2000, p. 399). We know that bullying invariably involves such a power imbalance, making the use of ADRs completely inappropriate.

The Mask of Counseling and Employee Assistance

Another sometimes inappropriate but frequently sought organizational response to bullying is the use of counseling via Employee Assistance Programs (EAPs). When a complaint is made, it is not unusual that both the target and the bully be made aware of EAP provisions in that organization. For the target, counseling with EAPs may be recommended as a support to deal with the stress that inevitably accompanies making a complaint. However, sometimes, support for the 'troubled worker' may have less to do with personal support and more to do with surveillance (Vickers \& Kouzmin, 2001).

Counseling can be provided through EAPs, which are often depicted as an evolving 'success story' of assistance by supposedly humanitarian organizations concerned for their staff. EAPs are supposedly provided out of concern for the organization's most precious commodity - their human resources - in a genuine and proactive developmental manner (Emener, 1997, p. 236). The trouble is, EAPs can also provide an endorsed means of surveillance and social control. Reports to managers of staff usage of EAP services, especially if usage is high, are not unusual, although rarely advertised (Vickers \& Kouzmin, 2001).

EAPs, ostensibly, were developed to provide support for organizational actors in "trouble." In many instances, they still provide a valuable service to staff experiencing personal grief, work conflicts, financial problems or relationship difficulties, providing counselling and referral services for a wide range of personal problems (Reynes, 1998, p. 73; Trice \& Beyer, 1984, p. 267). However, they are also used to provide training for supervisors to recognize and deal with 'troubled' employees (Reynes, 1998, p. 73), providing job-based programmes designed to identify and assist the troubled worker (Hartwell et al., 1996, p. 804). The 'troubled worker' (Hartwell et al., 1996, p. 804; Hopkins, 1997, p. 1216) may reflect the problem through tardiness, absenteeism or hostility (Reynes, 1998, p. 73) or through other, less discussible, behaviour-sexual misconduct, violence, drug abuse, sabotage. The troubled worker may also be identified if complaining of being bullied.

The rationale for employers providing counselling and support is largely associated with reducing costs, rehabilitating and retaining the troubled employee, enhancing management and labour relations, providing a benefit to employees and families that returns more than it costs, and projecting a "caring" image, both internally and externally (Challenger, 1997, pp. 45-46). Moreover, the provision of support services may, arguably, allow executives to employ the defence posturing of 'rationalization' (Kline, 1984, p. 20; Oldham \& Kleiner, 1990), allowing managers to justify to themselves (and to others) that the continuing barrage of injury that the organization may be responsible for (directly or indirectly) is being neatly, conveniently and humanely dealt with by the organization. EAPs can provide an adequate, 
if not "proper," organizational response for the "problem worker" (Vickers \& Kouzmin, 2001).

EAPs are also used to protect organizations against legislative requirements. In Australia, the Disability Discrimination Act (1992) (DDA) (Oss \& Clary, 1998, p. 20; Reynes, 1998, p. 73) and the New South Wales Occupational Health and Safety Act (Brooks, 1993; Marks, 1984, p. 10) provide examples. As noted above, criminal sanctions may be imposed on employers who breach the provisions of these legislative imperatives, given their duty of care (Brooks, 1993; Marks, 1984, p. 10; WorkCover New South Wales, 1995 , p. 4). Indeed, it has been argued that the primary purpose of such support services is to minimize wrongful dismissal suits (Gottlieb \& Conkling, 1995, p. 5). Thus, EAPs provide organizations with a means of reducing insurance premiums and lawsuits. EAPs are now associated with disability legislation, equal employment opportunity (EEO) initiatives, incidents of workplace violence (Oss \& Clary, 1998, p. 20), critical incident debriefing, crisis management, disability management, and stress (Oss \& Clary, 1998, p. 23). However, consider also the remaining ambivalence in the literature about EAPs, for example, the ideological conflict between social control through performance orientation, and humanitarianism (Trice \& Beyer, 1984, p. 245; Hopkins, 1997, p. 1225).

Bullies may also be sent for counselling. Indeed, predatory bullies may knowingly request counselling, even admit to some personal 'problem' requiring help, to avoid any punitive response from the organization. A calculating sociopath can easily construct a story of alcoholism or childhood abuse, attend counselling and, afterwards, return to their same abhorrent behaviour. Such an organizational response further trivializes the target's experience of being bullied, further adding to their humiliation and the bully's satisfaction.

\section{The Mask of Training}

Finally, I turn attention to one of the most frequent organizational responses to bullying; that is, to offer training courses to the target and/or the bully. For the target, courses in communication skills, conflict resolution, self-confidence and self-esteem are commonplace (e.g., New South Wales Nursing Association, 1999, pp. 12-15). These kinds of outcomes are based on the flawed assumption that targets are equally responsible for the problem of bullying, that the target needs to 'improve' in order for the bullying to stop, and that targets are somehow deficient in the skills offered in these courses. As previously noted, stereotypical thinking in this area confirms that, if only the target had been more assertive, a more proficient communicator, or in some way 'better,' the 'problem' would not have arisen.

Similarly, training may also be suggested for bullies on the basis that, if the bully realizes their wrongdoing, then the bullying will stop. The assumption here is that it is ignorance and misinformation that is the root of the problem, rather than some other motivation of the bully. However, there is no evidence that training will stop bullying. We know that the training propositions are founded on the belief that bullies do not realise that their behaviour is offensive to others. For example, proponents suggest that improvement of communication processes will help (Lewis, 1998, p. 87). Mediation and conflict management training has been used to help people learn to resolve conflicts in a peaceful way, rather than via force and aggression (Hinkle \& Henry, 2000). However, even those 
who do support the use of training, counselling, improved communication processes and giving perpetrators of bullying a chance to improve, caution that just 'a chance, not lots of chances' be given (Lewis, 1998, p. 87, my emphasis).

However, any use of conflict management training is inappropriate when considering predatory bullies. It is important to recognize that predatory or sociopathic bullies do what they do for the fun of it. Traditional training methods merely confirm the assumption that change will be or can be sought by the perpetrator. Some individuals cannot change; others may not want to. Unfortunately, many bullies are not especially predisposed or inclined to consider the self-respect or humanity of their targets. Sociopathic bullies (Cooper, 1999), in particular, are especially unlikely to change their behaviour. The psychopath (or sociopath, the more recent nomenclature for a psychiatric diagnosis) is notorious for being both charming and completely without remorse for even the most cruel and heartless acts. They are defined by their incapacity to feel empathy or compassion of any sort. They do not have the least twinge of conscience for what they do. Indeed, the cruelest and most sadistic of them delight in the suffering of their victims (Goleman, 1996, pp. 107-108). We know that violence prevention programs do not produce long-term changes in violent behaviour or decrease the risk of victimization (Casella, 2000, p. 325). Training will not necessarily result in any change in behaviour. Indeed, further knowledge and understanding of what they do may make them worse.

\section{Towards "Wellness in Organizations": Compassion for Individuals at Work}

Bullying is now recognized as a pervasive and disturbing workplace phenomenon, with significant costs to targets, communities and organizations. Economic and social conditions in the modern workplace tend to combine to create an environment very hospitable to bullying (Yamada, 2000). Unfortunately, legislation and policy initiatives designed to protect targets have the potential for paradoxical and unintended effects. Further, masks, such as those explored above, can serve to distort the real picture surrounding bullying, for example, what happened, who is at fault, what can be done to protect staff targeted, what works under these circumstances, and what does not. We have seen that masks serve to distort, to conceal, to hide and to protect. They ensure silence by offering an ameliorating face to a sometimes grotesque and flawed process.

So, what is to be done? I recommend two things. First, responses routinely applied to bullying cases should be cautiously and critically applied, especially if wellness in organizations - especially for individuals - is being sought. It is vital to recognize the potentiality for legislative and policy initiatives to have paradoxical and unintended outcomes. Recognition of such outcomes is a first step toward taking care in their application. Second, those involved with responding to bullying allegations internally to the organization should be aware of the masks that frequently arise in organizations to bolster the paradox. Each case should be very carefully considered before uncritical application of traditional solutions is undertaken.

We have seen that Masks and Paradoxes contribute to the problem of bullying in organizational life by ensuring that the phenomenon remains silenced, distorted, misrepresented and euphemized. The surest way to block wellness for individuals in 
organizations is to stay silent about what is really going on, and to continue as before, without question. For the mask to be lifted and the paradox addressed:

What cannot be talked about must be talked about. What must not be talked about must be talked about openly. What cannot and must not be felt must be given its hearing. We must have the courage to break the spell of our cherished workplace selfprotectiveness (Stein, 1998, pp. 13-14).

\section{References}

Adkins, J. (1999). Promoting organizational health: The evolving practice of occupational health psychology. Professional Psychology, Research and Practice, 30(2), 129-137.

Ballard, M., Argus, T., \& Remley, T. P. (1999). Bullying and school violence: A proposed prevention program. National Association of Secondary School Principals (NASSP) Bulletin, 83, 38-47.

Barron, O. (2002). Why workplace bullying and violence are different: Protecting employees from both. In M. Gill, B. Fisher \& V. Bowie (Eds.), Violence at work: Causes, patterns and prevention (pp. 151164). Cullompton, Devon, UK: Willan.

Blauner, R. (1964). Alienation and freedom: The factory worker and his industry. Chicago and London: The University of Chicago Press.

Braverman, H. (1994). The degradation of work. In H. Clark, J. Chandler, \& J. Barry (Eds.), Organisation and identities: Text and readings in organisational behaviour (pp. 385-387). London and Glasgow: Chapman \& Hall.

Brooks, A. S. (1993). Occupational health and safety law in Australia (4th edn.). Sydney: CCH Australia Limited.

Casella, R. (2000). The benefits of peer mediation in the context of urban conflict and program status. Urban Education, 35(3), 324-355.

Challenger, B. R. (1997). The need for employee assistance programmes, In W. S. Hutchison \& W. G. Emener (Eds.), Employee assistance programmes: A basic text (pp. 43-49). Springfield: Thomas.

Commonwealth of Australia (1996). Attorney General's Department. Disability Discrimination Act 1992. Canberra: Australian Government Publishing Service.

Commonwealth of Australia (1996). Attorney General's Department. Sex Discrimination Act 1984. Canberra: Commonwealth Government Printer.

Cooper, C. (1999). In my opinion. Management Today, June, 14-15.

Dent, K. (2002). Occupational health and safety legislation: Delivering safe systems and places of work. In: Occupational Stress Conference, PPL Education Services, Sydney, Australia, 20 November, 2002, $1-22$.

Emener, W. G. (1997). Human resource development in employee assistance programming: An overview. In W. S. Hutchison \& W. G. Emener, (Eds.), Employee assistance programmes: A basic text (pp. 231237). Springfield: Thomas.

Felson, R. B. (2000). A social psychological approach to interpersonal aggression. In V. B. Van Hasselt \& M. Hersen (Eds.), Aggression and violence: An introductory text (pp. 9-22). Boston and London: Allyn and Bacon.

Fineman, S. (1993). Organizations as emotional arenas. In S. Fineman (Ed.), Emotion in organizations (pp. 9-35). London, Thousand Oaks, New Delhi: Sage.

Fromm, E. (1963/1994). Alienation. In H. Clark, J. Chandler, \& J. Barry (Eds.), Organisation and identities: Text and readings in organisational behaviour (pp. 391-396). London, Glasgow, New York, Melbourne: Chapman \& Hall.

Frost, P. J. (2003). Toxic emotions at work: How compassionate managers handle pain and conflict (pp. 251). Boston, Massachusetts: Harvard Business School.

Gabriel, Y. (1998). An introduction to the social psychology of insults in organizations. Human Relations, 51(11), 1329-1354.

Gaymer, J. (1999). Assault course. Occupational Health, 51(2), 12-13. 
Goleman, D. (1996). Emotional intelligence: Why it can matter more than IQ. London, Great Britain: Bloomsbury.

Gottlieb, M. R., \& Conkling, L. (1995). Managing the workplace survivors: Organizational downsizing and the commitment gap. Westport: Quorum.

Hartwell, T. D., Steele, P., French, M. T., Potter, F. J., Rodman, N. F., \& Zarkin, G. A. (1996). Aiding troubled employees: The prevalence, cost, and characteristics of employee assistance programmes in the United States. The American Journal of Public Health, 86(6), 804-808.

Hinkle, W. G., \& Henry, S. (2000). Preface. Annals of the American Academy of Political and Social Science, 567, 8-14.

Hopkins, K. M. (1997). Supervisor intervention with troubled workers: A social identity perspective. Human Relations, 50(10), 1215-1238.

House of Representatives Standing Committee on Employment, Education and Training 1994 (1995). Bullying and school violence: Nature and effect of school violence. In Healey, K. (Ed.), Conflict Resolution: Issues for the Nineties (pp. 20-23). Sydney, Australia: Spinney.

Hutchinson, M., Vickers, M. H., Jackson, D., \& Wilkes, L. (2005). "I'm gonna do what I wanna do!": Organisational change as a vehicle for bullies. Health Care Management Review, 30(4), 331-338.

Hutchinson, M., Vickers, M. H., Jackson, D., \& Wilkes, L. (2006a). "They stand you in a corner and you are not to speak": Nurses tell of abusive indoctrination in work teams dominated by bullies. Contemporary Nurse, 21(2), 228-238.

Hutchinson, M., Vickers, M. H., Jackson, D., \& Wilkes, L. (2006b). Workplace bullying in nursing: Towards a more critical organisational perspective. Nursing Inquiry, 13(2), 118-126.

Imbrogno, A. R., \& Imbrogno, S. (2000). Mediation in court cases of domestic violence. Families in Society, 81(4), 392-401.

Kline, P. (1984). Psychology and freudian theory: An introduction. London: Methuen.

La Bier, D. (1986). Modern madness: The emotional fallout of success. Sydney: Addison-Wesley.

Lee, D. (2002). Gendered workplace bullying in the restructured UK civil service. Personnel Review, 31(2), 205-227.

Leymann, H., \& Gustafssson, A. (1996). Mobbing and the development of post traumatic stress disorders. European Journal of Work and Organizational Psychology, 5, 251-276.

Lewis, B. (1998). Training, communication can help eliminate staffs fear of bullying bosses. InfoWorld, 20 (47), 87.

Mann, R. (1996). Psychological abuse in the workplace. In P. McCarthy, M. Sheehan \& W. Wilkie (Eds.), Bullying: From backyard to boardroom (pp. 83-92). Sydney: Millennium, Beyond Bullying Association.

Marks, F. (1984). Drug and alcohol dependence in the workforce-Legal implications. In: Proceedings of the Third Occupational Drug and Alcohol Programmes Conference, Melbourne, October 10-12 1983, $9-15$.

Mayhew, C., \& Chappell, D. (2001) 'Internal' violence (or bullying) and the health workforce. Working paper series, In: Taskforce on the Prevention and Management of Violence in the Health Workplace. Sydney: Industrial Relations Research Center: University of New South Wales.

Mayhew, C., McCarthy, P., Chappell, D., Quinlan, M., Barker, M., \& Sheehan, M. (2004). Measuring the extent of impact from occupational violence and bullying on traumatised workers. Employee Responsibilities and Rights Journal, 16(3), 117-134.

McMahon, L. (2000). Bullying and harassment in the workplace. International Journal of Contemporary Hospitality Management, 12(6), 384-387.

New South Wales Nursing Association (1999). Those who can, do; those who can't bully. The Lamp, October, 12-15.

NSW Government Information Service (1977). New South Wales Anti-discrimination Act 1977 no. 48. Sydney, Australia: NSW Government Information Service.

Oldham, M., \& Kleiner, B. H. (1990). Understanding the nature and use of defence mechanisms in organizational life. Journal of Managerial Psychology, 5(5), i-iv.

Olweus, D. (1994). Bullying at school: Basic facts and effects of a school based intervention program. Journal of Child Psychology, 35, 1171-1190.

Oss, M. E., \& Clary, J. (1998). The evolving world of employee assistance. Behavioral Health Management, 18(4), 20-24.

Penguin English Dictionary (1992). London: Penguin. 
Perrone, J., \& Vickers, M. H. (2004). Emotions as strategic game in a hostile workplace: An exemplar case study. Employee Responsibilities and Rights Journal, 16(3), 167-178.

Powell, G. N. (1998). The abusive organization. Academy of Management Executive, 12(2), 95-96.

Quine, L. (1999).Workplace bullying in NHS community trust: Staff questionnaire survey. British Medical Journal, 318(7178), 228-232.

Randall, P. (1997). Adult bullying: Perpetrators and victims. London and New York: Routledge.

Rees, S. (1995). Greed and bullying. In S. Rees \& G. Rodley (Eds.), The human costs of managerialism: Advocating the recovery of humanity (pp. 197-210). Sydney, Australia: Pluto.

Reynes, R. (1998). Programs that aid troubled workers. Nation's Business, June, 73-74.

Stein, H. F. (1998). Euphemism, spin, and the crisis in organizational life. Westport, Connecticut and London: Quorum.

Stein, H. F. (2001). Nothing personal, just business: A guided journey into organizational darkness. Westport, Connecticut; London: Quorum.

Simpson, R., \& Cohen, C. (2004). Dangerous work: The gendered nature of bullying in the context of higher education. Gender, Work and Organization, 11(2), 163-186.

Tetrick, L. E. (2002). Individual and organizational health. Research in Occupational Stress and Well Being, 2, 117-141.

Thomson, D., \& Dunstan, D. (2002). Examining the relationship between and the effect of litigation on an injury. In: Occupational Stress Conference, PPL Education Services, Sydney, 20 November, 43-60.

Trice, H. M., \& Beyer, J. M. (1984). Employee assistance programmes: Blending performance-oriented and humanitarian ideologies to assist emotionally disturbed employees. Research in Community and Mental Health, 4, 245-297.

Trinca, H., \& Fox, C. (2004). Better than sex: How a whole generation got hooked on work. Sydney: Random House Australia.

University of Western Sydney (2003). Prevention of Harassment, Vilification and Bullying Policy, http:// apps.uws.edu.au/uws/policies/ppm/doc/000099.html.

Vickers, M. H. (1998). Life at work with "invisible" chronic illness (ICI): A passage of trauma-Turbulent, random, poignant. Administrative Theory and Praxis, 20(2), 196-210.

Vickers, M. H. (1999). "Sick" organisations, "rabid" managerialism: Work-life narratives from people with "invisible" chronic illness. Public Voices, 4(1), 59-82.

Vickers, M. H. (2001a) Work and unseen chronic illness: Silent voices. London and New York: Routledge.

Vickers, M. H. (2001b). Bullying as unacknowledged organizational evil: A researcher's story. Employee Responsibilities and Rights Journal, 13(4), 207-217.

Vickers, M. H. (2002). "People first-Always!": Values rhetoric to enhance betrayal—A downsizing case study. Employee Responsibilities and Rights Journal, 14(2), 207-217.

Vickers, M. H. (2004). The traumatised worker: A concern for employers and employees. Employee Responsibilities and Rights Journal, 16(3), 113-116.

Vickers, M. H., \& Kouzmin, A. (2001). Employee assistance programmes (EAPs): From crisis support to sanctioned coercion and panopticist practices. International Journal of Critical Psychology, 1(2), 61-83.

Vickers, M. H., Parris, M., \& Bailey, J. (2004). Working mothers of children with chronic illness: Narratives of working and caring. Australian Journal of Early Childhood, 20(1), 39-44.

Wallis Consulting (2001). Victorians' attitudes towards bullying. Carlton, Victoria: Wallis Consulting.

Wilkes, G. A. (Ed.) (1979). Collins Dictionary of the English Language. Sydney: Collins.

WorkCover New South Wales (1995). Drugs, alcohol and the workplace. Sydney: WorkCover Authority of NSW.

Yamada, D. C. (2000). The phenomenon of 'workplace bullying' and the need for status-blind hostile work environment protection. Georgetown Law Journal, 88(3), March, 475-536.

Zapf, D. (1999). Organisational, work group related and personal causes of mobbing/bullying at work. International Journal of Manpower, 20(1/2), 70-85. 